\title{
USAHA KEPALA MADRASAH TSANAWIYAH NEGERI (MTSN) BATUSANGKAR SEBAGAI SUPERVISOR DALAM MENINGKATKAN KUALITAS PEMBELAJARAN
}

\author{
Khairul Muslim \\ Guru MIS Batusangkar Kab. Tanah datar \\ Jl. Soekarno-Hatta Batusangkar, Sumatera Barat \\ e-mail: khairulmuslim22@gmail.com
}

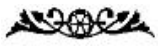

Abstract: This research begins of MTsN Batusangkar ranked champion always gets the best madrasah in Tanah Datar, both in terms of teacher quality, student quality and performance improvement headmaster, this is evidenced by the many accomplishments achieved by the madrasah. Both at the distric until province. This research is a qualitative research. Sources of primary data in this study is the head master of MTsN Batusangkar. Secondary data sources in this research is the Deputy Head Master, Head of Administration, teachers and students MTsN Batusangkar Tanah Datar District. Data collected by observation, interview and and document. The Data collection is done by the following steps, namely: data collection, data reduction, data display that has been analyzed and conclusions. The results of this study were, Planning of Head Master MTsN Batusangkar as a supervisor in improving the quality of learning is to plan the preparation of the program in one semester or yearly. The program is not overly rigid, depending on the number of teachers who need to be supervised. And also make a list of useful checklist sheet to check the completeness of the administration of learning tools for teachers. The Head Master of $M T s N$ implementation Batusangkar as a supervisor in improving the quality of learning is to conduct supervision of the implementation of education, that there are three forms of the implementation of educational supervision conducted by the Head MTsN Batusangkar namely planning, classroom observation and evaluation as individual talks, and a teachers' meeting. The evaluation forms of the Head $M T s N$ Batusangkar as a supervisor in improving the quality of teaching is that through the stages of individual talks and a teachers' meeting.
\end{abstract}

Keywords: Head Master, Supervisor, Quality of Education, MTsN Batusangkar

\section{PENDAHULUAN}

Kepala sekolah sebagai pengawas atau penilik juga merupakan supervisor. Namun sayangnya koordinasi antara keduanya dalam melaksanakan pembinaan terhadap pendidik dalam lembaga pendidikan Islam belum terjadi secara efektif. Data yang dikumpulkan oleh pengawas belum dapat dipadukan atau disinkronkan dengan data yang dikumpulkan oleh kepala sekolah.
Supervisor pendidikan bukan hanya pengawas resmi yang ditunjuk berdasarkan SK menteri pendidikan, ataupun kepala sekolah, tetapi kita bisa memanfaatkan guru-guru terpilih untuk memberikan supervisi kepada sesama rekan pengajar sesuai dengan bidang keahliannya dalam meningkatkan mutu di sekolah.

Kepala sekolah sebagai supervisor dalam melaksanakan supervisi harus mengetahui bahwa sesungguhnya supervisi 
tidak hanya mencakup kepemimpinan kepala sekolah, akan tetapi juga mencakup perbaikan situasi belajar mengajar dalam arti yang seluas-luasnya. Hal ini sesuai dengan pendapat yang dikemukakan oleh Piet A. Sahertian yang mengemukakan bahwa "sebagai seorang supervisor, kepala sekolah tidak hanya memikirkan bagaimana memimpin sekolah sebagaimana mestinya. Lebih dari itu, kepala sekolah juga harus mengupayakan agar perbaikan terhadap proses pembelajaran yang dilaksanakan oleh guru-guru” (Piet A, 2000).

Istilah supervisi pendidikan sering diartikan dalam kategori pembentukan mental, karena supervisi disebut juga pengawas atau kepengawasan. Supervisi secara etimologi berasal dari kata "super" dan "visi" yang mengandung arti melihat dan meninjau dari atas atau menilik dan menilai dari atas yang dilakukan pihak atasan terhadap aktivitas, kreativitas, dan kinerja bawahan. Menurut konsep kuno, supervisi dilaksanakan dalam bentuk inspeksi atau mencari kesalahan, sedangkan dalam pandangan modern, supervisi adalah usaha untuk memperbaiki situasi belajar mengajar yaitu sebagai salah satu bentuk bimbingan bagi guru dalam mengajar untuk membantu siswa agar lebih baik dalam proses belajar mengajar.

Konsep peningkatan kualitas pendidikan merupakan salah satu unsur dari paradigma baru pengelolaan pendidikan di Indonesia. Paradigma tersebut mengandung atribut pokok, yaitu relevan dengan kebutuhan masyarakat pengguna lulusan, suasana akademik yang kondusif dalam penyelenggaraan program studi, adanya komitmen kelembagaan dari para pimpinan dan staf terhadap pengelolaan organisasi yang efektif dan produktif, keberlanjutan program studi, serta efisiensi program secara selektif berdasarkan kelayakan dan kecukupan. Dimensi-dimensi tersebut mempunyai kedudukan dan fungsi yang sangat strategis untuk merancang dan mengembangkan usaha penyelenggaraan pendidikan yang berorientasi kualitas pada masa yang akan datang.

MTsN Batusangkar selalu mendapat juara peringkat madrasah terbaik di kabupaten Tanah Datar, baik dari segi kualitas guru, kualitas siswa dan peningkatan kinerja kepala madrasah. Hal ini dibuktikan dengan banyaknya prestasi yang diraih oleh madrasah. Baik di tingkat kabupaten, propinsi dalam bidang studi Qur'an Hadist bahkan sampai ketingkat Propinsi, hal ini dibuktikan dengan adanya Surat Keputusan dari Kantor Kemeterian Agama Wilayah Sumatera Barat dan piagam penghargaan dari Kantor Kementerian Agama Kabupaten Tanah Datar.

Untuk mencapai visi misi dan tujuan MTsN Batusangkar maka dilakukan hal seperti menciptakan administrasi perkantoran yang baik, karena administrasi perkantoran adalah aspek yang dinamis dalam mencapai keberhasilan secara maksimal. Keberhasilan administrasi perkantoran MTsN Batusangkar juga dipengaruhi oleh tujuan, manfaat dan kegiatan administrasi perkantoran serta sumber daya manusia dalam mengelola tata usaha MTsN Batusangkar. MTsN Batusangkar memiliki 10 orang pegawai dalam memberikan pelayanan kepada guru dan siswa.

Kepala MTsN Batusangkar mengevaluasi hasil supervisi tersebut, dengan cara 
memanggil guru yang sudah disupervisi untuk mengevaluasi tentang pembelajaran yang sudah dilakukannya. Bahkan kepala sekolah di MTsN Batusangkar sering mengundang pakar pendidikan untuk memberikan pelatihan dan diklat untuk para guru MTsN Batusangkar.

\section{PEMBAHASAN}

\section{Kepala Sekolah/Madrasah}

Secara etimologi menurut kamus besar bahasa Indonesia, kepala madrasah "orang atau guru yang memimpin suatu madrasah". Dengan demikian kepala madrasah merupakan pihak yang ditunjuk untuk memimpin suatu lembaga pendidikan.

Sedangkan secara terminologi, (Wahjosumidjo, 1999) mengemukakan pengertian kepala madrasah adalah sebagai seorang tenaga profesional guru yang diberi tugas untuk memimpin suatu madrasah di mana diselenggarakan proses belajar mengajar" atau "tempat dimana terjadi interaksi antara guru yang memberi pelajaran dan murid yang menerima pelajaran.

Definisi lain tentang pengertian kepala madrasah adalah "orang yang bertugas sebagai pemegang policy umum dalam menentukan kebijakan dilingkungan madrasah". Definisi yang hampir bersamaan dikemukakan pula bahwa kepala sekolah merupakan "seseorang yang bertanggung jawab kepada atasannya terhadap tugas yang telah dipikulkan kepadanya pada lingkungan lembaga pendidikan".

Berdasarkan pengertian di atas dapat dipahami bahwa kepala madrasah merupakan pihak yang bertanggung jawab dalam pelaksanaan pendidikan di lembaga yang dipimpinnya. Sebagai pihak yang bertanggungjawab dalam pelaksanaan proses kependidikan di madrasah, kepala madrasah memegang kebijaksanaan tentang pengembangan lembaga pendidikan yang dipimpin tersebut. Apapun pekerjaan yang dilakukan dalam memimpin lembaga pendidikan tersebut berkaitan dengan proses pertanggungjawaban yang harus disampaikan kepada atasannya secara langsung.

Fungsi kepala madrasah adalah menciptakan suasana kerja yang kondusif dalam pelaksanaan tugas-tugas di madrasah. Pendapat yang hampir sama dikemukakan pula oleh Hendiyat Soetopo dan Wasty Soemanto yang mengatakan bahwa fungsi kepala madrasah sebagai pemimpin pendidikan dibagi atas 2 bagian, yaitu pertama berkaitan dengan tujuan yang hendak dicapai dengan memaksimalkan tujuan kelompok serta menjelaskan supaya anggota dapat menyadari dalam bekerjasama mencapai tujuan itu, kedua fungsi kepala madrasah yang berkaitan dengan penciptaan suasana pekerjaan yang sehat dengan menanamkan dan memupuk kesediaan bekerjasama di dalam kelompok ataupun mempergunakan kelebihan-kelebihan yang terdapat pada pimpinan untuk memberikan sumbangan dalam kelompok menuju pencapaian tujuan bersama (Soetopo dkk, 1988).

\section{Supervisi}

Supervisi pendidikan sangat erat kaitannya dengan pimpinan dan bawahan dalam bidang pendidikan, yang lebih di 
kenal dengan kepala madrasah dengan guru. Guru dalam menjalankan tugasnya membutuhkan bantuan orang lain dalam hal memecahkan masalah-masalah yang dihadapinya untuk mewujudkan tujuan pendidikan. Misalnya untuk mengerti tujuan pendidikan, tujuan kurikuler dan tujuan instruksional. Kemudian arahan dan bimbingan yang diberikan terhadap para guru dikenal dengan supervisi, sedangkan orang yang bertugas membantu guru untuk mengatasi masalah yang dihadapi adalah kepala madrasah.

Ditinjau dari segi etimologi supervisi berasal dari bahasa Inggris yaitu "super" dan "vision". Super berarti atas atau lebih sedangkan vision berarti melihat atau meninjau. Jadi pengertian supervisi berarti meninjau dari atas atau menilik atau menilai dari atas, yang dilakukan oleh pihak atasan (orang yang memiliki kelebihan kerja bawahannya (Hadari, 1982).

Selain itu, Amentembun mengartikan "supervisi" dengan kata lain pembinaan yang mengandung arti perkembangan apa yang telah ada menjadi lebih baik.Jadi supervisi tidak hanya sekedar melihat dan menilai, tetapi lebih mementingkan pembinaan, dengan tujuan bukan mencari kelemahan orang yang disupervisi melainkan untuk membantu mereka mengembangkan kemampuannya. Di samping itu, banyak para ahli yang mengemukakan pendapat tentang supervisi antara lain,

a. Menurut P. Adams dan Frank G. Dickey, Supervisi adalah suatu program berencana untuk memperbaiki pengajaran (supervision is a plenneel program for the improvement of instruction). b. Dalam dictionary of education good center memberikan pengertian supervisi sebagai berikut, Segala usaha dari petugaspetugas madrasah dalam memimpin guru dan petugas lainnya dalam memperbaiki pengajaran termasuk menstimulir, menyeleksi pertumbuhan jabatan dan perkembangan guru-guru dan merevisi tujuan-tujuan pendidikan, bahan-bahan pengajaran, metode mengajar dan evaluasi pengajaran.

Dengan demikian dapat disimpulkan bahwa tujuan dari pelaksanaan supervisi pendidikan adalah untuk dapat membina perilaku mengajar guru yang berkualitas, sehingga terciptalah perilaku belajar murid dengan hasil yang lebih baik.Namun, tujuan supervisi pendidikan tidak hanya mencari kekurangan dan kelemahan yang dimiliki guru, tetapi harus dapat memperhatikan dan memanfaatkan kemampuan yang ada pada petugas pendidikan (guru). Adapun kemampuan yang dimiliki oleh setiap guru dinamakan kemampuan dalam belajar, yaitu kemampuan itu mencakup ke dalam berbagai segi dengan macam-macam unsurnya yaitu, (Rifai, 1982):

1) Segi pengetahuan mencakup

a) Penguasaan materi bidang studi yang diajarkan.

b) Pengetahuan tentang berbagai metode.

c) Pengetahuan tentang berbagai alat pelajaran.

d) Pengetahuan tentang keadaan murid.

2) Segi keterampilan dan kemampuan mengajar

a) Keterampilan berkomunikasi dan menggunakan bahasa. 
b) Keterampilan memilih dan menerapkan metode dan pengajaran.

c) Keterampilan bertanya dan menyusun pertanyaan.

d) Keterampilan dan kemampuan alatalat pelajaran

3) Segi sikap dan kemampuan mengajar

a) Menyukai murid

b) Jujur terhadap diri sendiri dan terhadap murid

c) Disiplin terhadap tugas dan diri sendiri.

d) Keterbukaan yang menimbulkan prasangka.

Dari kutipan di atas menunjukkan dan mengatasi bahwa seorang guru harus memiliki kemampuan untuk menjelaskan dan mengatasi persoalan yang dihadapi dalam proses belajar mengajar yang mencakup kegiatan manajemen kelas, mengatasi masalah disiplin, menciptakan iklim yang menyenangkan, menghadapi berbagai prilaku siswa. Semua itu harus dapat diatasi oleh para guru dengan berbagai alternatif pemecahan masalah, kemampuan ini juga mewujudkan suatu alternatif pemecahan masalah.

Model-model supervisi dalam pendidikan, yaitu:

a. Model supervisi konvensional. Supervisor mengadakan inspeksi untuk mencari serta menemukan kesalahan. Kadang model ini bersifat memata-matai dan menggurui.

b. Model Supervisi yang bersifat ilmiah. Supervisi ini dilaksanakan secara berencana, kontinu, sistematis, dengan menggunakan menggunakan prosedur dan teknik tertentu, serta instrumen pengumpulan data, sehingga memperoleh data yang objektif dari keadaan yang sebenarnya.

c. Model supervisi klinis, merupakan suatu proses bimbingan dalam pendidikan yang bertujuan membantu pengembangan profesional guru khususnya dalam penampilan mengajar, berdasarkan observasi dan analisis data secara teliti dan objektif sebagai pegangan untuk perbaikan tingkah laku mengajar guru.

d. Model supervisi artistik, memandang bahwa mengajar adalah suatu pengetahuan (knowledge), mengajar itu suatu keterampilan (skill), tetapi mengajar juga suatu kiat (art). Demikian juga dengan supervisi, yang merupakan suatu pengetahuan, suatu keterampilan dan juga suatu kiat (artistik).

\section{Kualitas Pembelajaran}

Kualitas (mutu) adalah taraf atau derajat kepandaian dan pengetahuan. Pendidikan secara lembaga dapat diartikan sebagai perbuatan (hal, cara, dan sebagainya) mendidik dan berarti pula pengetahuan tentang mendidik atau pemeliharaan (latihan-latihan dan sebagainya) badan, bathin dan sebagainya.

Adapun pengertian pendidikan dari segi istilah kita dapat merujuk kepada berbagai sumber yang diberikan oleh para ahli pendidikan. Dalam UU sistim Pendidikan Nasional No. 20 tahun 2003, Bab I pasal I ayat I dinyatakan, bahwa pendidikan adalah usaha sadar dan terencana untuk mewujudkan suasana belajar dan proses pembelajaran agar peserta didik secara aktif mengembangkan 
potensi dirinya untuk memiliki wawasan spritual keagamaan, pengendalian diri, kepribadian, kecerdasan, akhlak mulia, serta keterampilan yang diperlukan dirinya, masyarakat, bangsa, dan negara (Dirjen Pendis, 2006).

Kemudian Bapak pendidikan nasional Ki Hajar Dewantara menyatakan bahwa pendidikan berarti daya upaya untuk memajukan pertumbuhan budi pekerti, (kekuatan bathin karakter) pikiran (intelek) dan anak antara yang satu dengan yang lainnya saling berhubungan agar dapat memajukan kemampuan hidup yakni, kehidupan dan penghidupan anak-anak yang kita didik selaras dengan duniawinya (Abudinata, 1999).

Dari defenisi di atas dapat diketahui bahwa pendidikan adalah suatu usaha atau proses yang bertujuan untuk membentuk manusia berkualitas agar dapat melakukan peranannya dalam kehidupan secara fungsional dan optimal. Jadi intinya pendidikan tersebut merupakan suatu usaha menolong manusia agar dapat memajukan eksistensinya secara fungsional ditengahtengah masyarakat dan teman sejawatnya.

Pendidikan yang berkualitas akan melahirkan manusia yang berkualitas, dan manusia yang berkualitas mempunyai ciriciri sebagai berikut:

a. Beriman dan bertaqwa kepada Tuhan Yang Maha Esa yang dicirikan antara lain dengan kejujuran dan ahklak yang mulia.

b. Berbudaya Iptek sehingga mampu menerapkan, mengembangkan dan menguasai Iptek yang berakar pada nilai-nilai budaya bangsa Indonesia. c. Menghargai waktu dan mempunyai etis kerja dan kedisiplinan yang tinggi.

d. Kreatif, produktif, efesiensi dan berwawasan keunggulan

e. Mempunyai wawasan, kewiraswastaan dan kemampuan memanajemen yang handal

f. Mempunyai daya juang yang tinggi

g. Mempunyai wawasan kebangsaan yang tinggi, dengan mengutamakan kesatuan dan persatuan bangsa

h. Mempunyai tanggung jawab dan sosialitas sosial yang tinggi.

i. Mempunyai keteguhan moral yang kuat sehingga tidak terpengaruh oleh arus negatif globalisasi.

j. Mempunyai kesehatan fisik yang prima sehingga dapat berfikir dan bekerja secara produktif.

\section{METODE PENELITIAN}

Penelitian ini termasuk dalam kategori penelitian lapangan (field research). Sedangkan dalam pembahasan tesis ini penulis menggunakan metode deskriptif, yaitu penelitian yang mengemukakan gambaran tentang fakta-fakta yang terjadi di lokasi penelitian. Fakta-fakta yang akan penulis gambarkan dalam tulisan ini berkenaan dengan usaha kepala MTsN Batusangkar, kabupaten Tanah Datar sebagai supervisor dalam meningkatkan kualitas pembelajaran.

Sumber data dalam penelitian ini terdiri dari dua jenis, terdiri dari:

1. Sumber data primer, merupakan sumber data pokok yang sangat terkait dengan permasalahan yang dibahas. Sumber data primer dalam penelitian ini adalah kepala MTsN Batusangkar, kabupaten Tanah Datar. 
2. Sumber data sekunder dalam penelitian ini adalah Wakil Kepala, Kepala Bagian Tata Usaha, guru serta siswa MTsN Batusangkar, kabupaten Tanah Datar. Sumber data sekunder dalam peneliti ini adalah sumber data yang terkait dengan permasalahan yang dibahas sebagai sumber pendukung. Hal ini sesuai dengan pendapat yang dikemukakan oleh Winarno Surakhmad bahwa sumber data sekunder merupakan sumber data yang terkait dengan permasalahan yang dibahas oleh peneliti (Winarno, 2001).

Teknik pengumpulan data dilakukan dengan observasi, wawancara dan studi dokumentasi. Pengumpulan data dilakukan dengan langkah berikut, yaitu: pengumpulan data, reduksi data, display data yang sudah dianalisis dan kesimpulan.

1. Dalam melakukan studi dokumentasi peneliti mengklasifikasikan dukumenn ke dalam 2 jenis, yaitu:

a. Soft copy, yaitu dokumen yang peneliti dapat dari tempat penyimpanan data seperti komputer dan laptop.

b. Hard copy, yaitu dokumentasi pada sekolah yang ada di dalam file penyimpanan dokumentasi, seperti laporan kegiatan sekolah dan fotofoto kegiatan sekolah.

2. Dalam melakukan wawancara penulis menggunakan alat berupa:

a. Pedoman wawancara yang menguraikan poin-poin khusus yang penting yang didiskusikan dengan informan, yaitu guru, siswa dan karyawan.

b. Buku catatan berfungsi untuk mencatat semua percakapan dengan informan. c. Kamera berfungsi untuk mengambil gambar dan video pada saat melakukan wawancara sehingga dapat dimafaatkan sebagai bukti penelitian.

d. Alat-alat lain yang dirasakan perlu.

3. Dalam melakukan observasi penulis menggunakan alat berupa foto digital, perakam video dan buku untuk menuliskan hal-hal yang didapati langsung atau tidak langsung.

\section{HASIL DAN PEMBAHASAN}

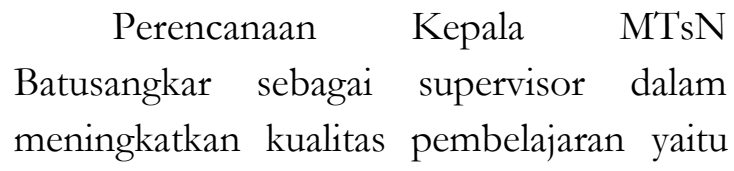
dengan merencanakan penyusunan program dalam satu semester atau tahunan. Program tidak terlalu kaku, tergantung dari jumlah guru yang perlu di supervisi dan juga membuat daftar lembar ceklis yang berguna untuk mengecek kelengkapan administrasi perangkat pembelajaran para guru.

Kepala Madrasah MTsN Batusangkar, secara teknis merencanakan lima langkah utama bagi terlaksananya supervisi dengan baik, yaitu:

1. Menciptakan suasana yang harmonis antara supervisor yaitu kepala madrasah dengan guru yang akan disupervisi.

2. Mengkaji ulang rencana pelajaran serta tujuan pelajaran.

3. Mengkaji ulang komponen keterampilan yang akan dilatihkan dan diamati.

4. Memilih atau mengembangkan suatu instrumen observasi yang akan dipakai untuk merekam tingkah laku guru yang akan menjadi perhatian utamanya. 
5. Instrumen observasi yang dipilih atau yang dikembangkan dibicarakan bersama antara guru dan supervisor

Dalam pelaksanaannya, Kepala MTsN Batusangkar sebagai supervisor untuk meningkatkan kualitas pembelajaran adalah dengan mengadakan pelaksanaan supervisi pendidikan, yaitu terdapat tiga bentuk pelaksanaan supervisi pendidikan yang sering dilakukan oleh kepala MTsN Batusangkar yaitu tahap perencanaan, observasi kelas, dan evaluasi seperti pembicaraan individual, dan rapat guru.

Pelaksanaan supervisi, ditemukan data sebagai berikut:

1. Memperbaiki personel guru yang sudah ada supaya lebih mengerti dan memahami materill mata pelajaran yang diajarkannya kepada siswa dan siswinya

2. Menyediakan materill yang memadai sesuai dengan kebutuhan, seperti alat dan media yang mendukung proses pembelajaran

3. Jika ada kekurangan guru, maka peneliti mencarikan guru yang memang mau dan mempunyai profesionalisme dalam mata pelajaran yang dicarikan tersebut.

Pelaksanaan supervisi pengajaran dapat terlaksana dengan semaksimal mungkin, baik yang berkaitan dengan personel guru maupun masalah materill yang akan disiapkan oleh kepala madrasah untuk mencapai tujuan pendidikan nasional.Bentuk evaluasi Kepala MTsN Batusangkar sebagai supervisor dalam meningkatkan kualitas pembelajaran adalah evaluasi pelaksanaan supervisi dalam meningkatkan profesionalisme guru di MTsN Batusangkar berjalan dengan baik dalam rangka peningkatan profesionalisme guru, yaitu melalui tahap pembicaraan individual dan rapat guru.

Cara memperbaiki personel guru adalah:

1. Menyarankan kepada guru supaya banyak membaca buku yang memang berkaitan dengan mata pelajaran yang diajarkannya

2. Memberi kesempatan kepada guru untuk melanjutkan pendidikan dengan cara mengatur jadwal mengajar guru tersebut supaya tidak terjadinya hal-hal yang membawa kepada pengaruh negatif.

Cara memperbaiki guru dari segi materil yaitu dengan cara:

1. Menyediakan buku-buku yang dibutuhkan oleh guru tersebut dalam proses pembelajaran

2. Menyediakan alat dan media yang mendukung pelajaran.

Rapat guru di MTsN Batusangkar ialah untuk menyelenggarakan pertemuan seperti diskusi panel, seminar, lokakarya, komperensi, kelompok studi, pekerjaan komisi, dan kegiatan lainya, dengan tujuan membicarakan masalah yang sama tentang pendidikan dan pengajaran. Kaitannya dengan peningkatan profesionalisme guru, rapat guru ini merupakan salah satu point yang mampu menghantarkan seorang menjadi profesional, karena rapat guru ini mengacu kepada perbaikan apabila guruguru mengalami masalah yang sama, dan rapat guru ini juga bertujuan untuk pengembangan kemampuan personel dan perkembangan profesinya. 


\section{PENUTUP}

\section{Kesimpulan}

Perencanaan Kepala MTsN Batusangkar Sebagai Supervisor dalam Meningkatkan Kualitas Pembelajaran yaitu dengan merencanakan penyusunan program dalam satu semester atau tahunan. Program tidak terlalu kaku, tergantung dari jumlah guru yang perlu di supervisi. Dan juga membuat daftar lembar ceklis yang berguna untuk mengecek kelengkapan administrasi perangkat pembelajaran para guru. Bentuk Pelaksanaan kepala MTsN Batusangkar sebagai Supervisor dalam Meningkatkan Kualitas Pembelajaran adalah dengan mengadakan pelaksanaan supervisi pendidikan, terdapat tiga bentuk pelaksanaan supervisi pendidikan yang sering dilakukan oleh kepala MTsN Batusangkar yaitu tahap perencanaan, observasi kelas, dan evaluasi seperti pembicaraan individual, dan rapat guru. Bentuk Evaluasi Kepala MTsN Batusangkar sebagai supervisor dalam Meningkatkan Kualitas Pembelajaran adalah evaluasi pelaksanaan supervisi dalam meningkatkan profesionalisme guru di MTsN Batusangkar sangat efektif dalam rangka peningkatan profesionalisme guru, yaitu melalui tahap pembicaraan individual dan rapat guru.

\section{Saran}

a. Diharapkan kepada Kepala MTsN Batusangkaragar lebih memperhatikan kinerja guru dalam proses pembelajaran, yaitu dengan memperbanyak metode dalam pengajaran.

b. Diharapkan kepada sesama guru agar saling mengkoreksi diri dalam rangka perbaikan untuk dapat melaksanakan pembelaran ke arah yang lebih baik. c. Diharapkan kepada pengawas sekolah secara berkala membimbing Kepala MTsN Batusangkar, guru dan tenaga kependidikan untuk melaksanakan pengelolaan dan bimbingan secara kontiniutas, agar tercapainya tujuan madrasah.

d. Diharapkan kepada Dinas Pendidikan dan Kementerian Agama untuk dapat meningkatkan kompetensi dan pengetahuan Kepala Madrasah, komite sekolah, pendidik (guru) dan tata usaha sekolah agar tertatanamnya kinerja yang baik.

\section{KEPUSTAKAAN ACUAN}

Abudinata, Metodologi Studi Islam, Jakarta: PT. Raja Grafindo Persada, 1999)

Departemen Agama RI., Wawasan Tugas Guru dan Tenaga Kependidikan, (Jakarta: Dirjen Kelembagaan Agama Islam, 2005)

Dirjen Pendidikan Islam, UU dan Peraturan Pemerintah RI tentang Pendidikan Islam, (Jakarta: Depaq, 2006)

Soetopo Hendayani dan Soemonto Wasty, Kepemimpinan Dan Supervisi Pendidikan, (Jakarta: Bina Aksara, 1988), Cet Ke2

Nawawi, Hadari, Administrasi Pendidikan, (Jakarta: Haji Mas Agung, 1988), Cet. Ke-6

Purwanto, M. Ngalim, Administrasi dan Supervisi Pendidikan, (Bandung: PT. Remaja Rosdakarya, 2004)

Rifa'i. Moh. M. Administrasi Dan Supervisi Pendidikan, (Jakarta: Tarsito, 1982) 
Sahertian A. Piet dan Mateheru Frans, Prinsip Dan Teknis Supervisi Pendidikan, (Surabaya: Usaha Nasional, 1981)

Wahjosumidjo, Kepeminpinan Kepala Madrasab Tinjauan Teoritik dan
Permasalahan, (Jakarta: Raja Grafindo Persada, 1999)

Winarno Surakhmad, Penelitian Pendidikan, (Jakarta: Rineka Cipta, 2001), Cet. Ke-6 